\title{
Transformations in Network Governance: The Case of Migration Intermediaries
}

\author{
Dimitria Groutsis \\ Diane van den Broek \\ William Harvey
}

\begin{abstract}
Market liberalisation has fundamentally changed state interventions in the supply of services and supportive infrastructure across a range of public services. While this trend has been relatively well documented, there has been a dearth of research into the changing nature of state interventions in migration and mobility. Indeed the increasing presence of migration intermediaries to service the many and varied needs of migrant workers, particularly skilled migrants, remains significantly under-researched both theoretically and empirically. In providing an analysis of the location, role and changing nature of migration intermediaries, we highlight the implications of commercially-driven governance structures. In particular we suggest that the shift from government to network governance has important implications for skilled migration including: inequities in access to information regarding the process of migration and labour market integration; and, greater dependence on (largely unregulated) private intermediaries. Accordingly, we present empirical examples of migration intermediaries to illustrate their role and the relationship with and implications of their exchange with migrants.
\end{abstract}

Keywords: Network governance, Intermediaries, Skilled migration, Commercialisation

\section{Introduction: Defining Migration Intermediaries}

Set against a backdrop of market liberalisation, a 'hollowing out' and de-centering of state mobilised services, support, and infrastructure has developed since the late 1980s (Fauser, 2014; Geddes et al 2012a, 2012b). The shift from government to network governance has been described as a shift from 'command-and-control' to 'arms length' management of state services by government agencies (Hysing 2009). This devolution of services to private agents in a variety of different publicly administered areas signals a transfer of authority and decision-making power from state-owned and managed institutional arrangements, to market-based interests (see for instance Bevir 2010; Rhodes 1997). Rhodes $(1997,109)$ argues that the shift to network governance means there is: "no one centre but multiple centres; there is no sovereign authority because networks have considerable autonomy." 
While studies of migrant mobility have often focused on explanations of why individuals and/or families migrate (de Haas 2010; Straubhaar 2000), the agents who procure migrant workers and mediate and facilitate the process of migration are portrayed as little more than 'passive' or 'neutral' players. Furthermore, the differentiation between migrant channels (Findlay and Li, 1998) and the commercial exchange that has intensified between the migrant and the various agents has also been largely neglected (Krissman 2005; Salt and Stein 1997; Sporton 2013).

When compared to the decades following the post World War II period, the migration process is now far more responsive to market (demand) conditions (Favell and Hanson 2002). This trend has consolidated non-state agencies as principal managing agent of the migration of international labour, particularly throughout the OECD (OECD 2011, 2012). For example, the changing context of migration has resulted in the proliferation of a suite of non-state bodies and commercially-driven agents including: recruitment and migration agents, employers and managers, independent contractors and educational institutions, to name a few (Elrick and Lewandowska 2008; Pijpers 2010).

The dominant pattern of migration is now directly shaped by national markets demanding ready, accessible, skilled and flexible labour which is being sourced outside national boundaries (OECD 2011, 2012). Relatedly, feeding into this transition to market-driven migration has been the pool of available, educated, mobile and skilled stocks of labour (Harvey and Groutsis 2012).

While there is an extensive scholarship examining the 'illegitimate' side of migration intermediaries, such as traffickers of irregular migrants and refugees (Fernandez 
2013; Leman and Janssens 2007; Salt and Stein, 1997; Triandafyllidou and Maroukis 2012), to date, little is known about the various agents servicing the needs of skilled migrants. There is also, at best, a partial understanding of why and how they have emerged and the implications of the relations forged between intermediaries and skilled migrants. Addressing this oversight is important given the market orientation of international migration, and the rise of new actors responsible for administering the migration process (Favell and Hanson 2002).

With the migration process broken up into a number of phases from the pre-migration stage through to integration in the destination country, we define migration intermediaries as agents that intervene at various critical junctures to connect the migrant to the destination country labour market. This paper segments intervention between the migrant and the intermediary into three distinct phases: from the premigration stage through to post-settlement integration. Unlike Findlay and Li (1998) who see intermediary agencies as including intercompany transfer infrastructure, we focus on the self-initiated and self-funded agent-migrant relationship at the meso level of analysis. While so, we agree that all intermediaries ".... naturally interface with the barriers and obstacles of state immigration legislation as well as with the less tangible obstacles restricting entry to foreign labor and housing markets" (Findlay and Li 1998, 683). This point clearly identifies the connections between the meso-level and other levels of analysis and, formal and informal and tangible and less tangible dimensions. Elrick and Lewandowska $(2008,722)$ bring similar characteristics to light in their work which differentiates between agents who gain material rewards and intermediaries who receive non-financial rewards for services rendered in the process of facilitating migration. Similar to the work of Elrick and Lewandowska (2008) we 
focus on the commercially-driven or financial exchange between the migrant and the agent, but we depart from them by using the terms agent and intermediary interchangeably to denote these market-based interests; and, our focus is on skilled rather than low-skilled migrants.

Contextual similarities can be drawn with the work on labour market intermediaries (Coe. et. al. 2010; Forde, 2008; Gonos, 1997; Hoque et. al. 2011; McDowell et. al. 2007), which highlights how intermediaries rely on political involvement to secure legitimisation. This legitimacy in effect allows these agents to sidestep the 'traditional' mediators in the attraction, allocation and integration of, in this case: migrant workers. While lessons from this scholarship are useful in establishing a bridge between the context set by the transitions in governance structures and migration processes, it is important to note the limitations given that migration intermediaries represent a broader construct. For example, they mediate different aspects of the migration process, influencing and shaping the decision to migrate; they facilitate entry into the labour market and are responsible for integration. Coe et al.'s work (2010) captures the complexity of intermediaries, noting that in spite of incorporating a globally interconnected network of agents and stakeholders, intermediaries are territorially embedded within nationally-specific employment relations regimes and therefore bound by conventions, rules, laws and policies that are set within these boundaries. Accordingly, while it is true that we can draw particular generalisations of the marketisation of the migration process, it is also true that we cannot assume that migration intermediaries are a homogenous entity internationally and/or regionally (Coe et. al. 2010, 1058, 1065). 
Our definition is also informed by the work of Agunias $(2009,2)$ who states that: "Intermediaries are key actors that facilitate, and sometimes drive, migration within and across borders. By providing information and extending critical services in many stages of migration and in places of origin, transit and destination, legitimate intermediaries build migrants' capabilities and expand their range of choice." We refine this definition by drawing on Salt and Stein's work (1997), categorising intermediary relations/intervention into three key phases: phase one, includes mobilisation and attraction; phase two includes allocation and labour market navigation/entry; and, phase three involves allocation and integration. These three phases are not mutually exclusive but interdependent.

This research argues that given their provision of information and support structures, migration intermediaries play an important role in facilitating the decision to migrate and integrating migrants into the destination country labour market (Harvey and Groutsis 2012; Salt and Stein 1997). As such, irrespective of the depth of their involvement in the migration process, migrants are dependent on their services (Findlay and Li 1998, 682) and beholden to their financial demands (Agunias 2009; Salt and Stein 1997).

This research extends our understanding of the nature and implications of changed relations between skilled migrants and the network of intermediaries available to them. In tracing the state's withdrawal of authority to these agencies, our paper highlights the escalation of meso-level commercially-driven arrangements that have come to work alongside macro-level institutional agents and micro-level kinship and friendship networks. By drawing on a broad suite of scholarship including, 
governance and migration and, literature examining labour market intermediaries, the paper highlights the implications for the migrant given their variable purchasing power, in accessing adequate and timely information and assistance in the process of migration and labour market integration. Most particularly it highlights how migrants increasingly shoulder the 'risks' of international mobility.

We begin by highlighting the shift from 'direct' government management to 'arms length' governance strategies of migration. We then critically evaluate how migration intermediaries have been located by turning attention to migration scholars. This is followed by empirical examples of migration intermediaries, which are categorised within the three phases outlined earlier (mobilisation and attraction; allocation and labour market navigation/entry; allocation and integration). These examples illustrate the changing connections between migration intermediaries and the migrants they serve. We conclude by identifying the importance of examining the contemporary transformation of migration intermediaries to further an understanding of the escalating risk factors for migrants and potential ways such risks can be minimised.

\section{Transitions from Government to Network Governance}

To explain transitions in migration intermediaries we draw on Rhodes' on-going research (Rhodes 1997, 1998, 2003, 2007), identifying the shift in policy administration from government to network governance. Rhodes indicates that in spite of a diversity of political traditions and systems, there has been a global convergence away from direct government policy administration toward the management of public services by a network of agents, by-passing the state entirely or working in partnership with it. While power to allocate resources (including labour to 
large public infrastructure projects) was, in the past, the main preserve of government agencies, commercially-driven interests have increasingly assumed this responsibility (Wright 2012). Of Rhodes' analysis, Mette Kjaer notes (2011, 102): “By pointing at the many simultaneous processes of 'hollowing out', Rhodes' analyses demonstrated that the central state was losing steering capacity."

Ultimately, Rhodes states $(2007,1251)$ : "the history of governance during the $20^{\text {th }}$ century appears as a shifting balance between government and governance.” As such the notion of an historical 'turn' invites us to consider the transformation toward, and the implications of, the 'hollowing out' of government and the concomitant emergence of a network of (commercially-driven) agents over time. Rhodes' treatment captures the fluid context within which relational exchanges occur (between parties) and the temporal and dynamic nature of these relations, while also highlighting the shifting trends toward multiple agents (Rhodes 2007,1250). Accordingly, this approach allows us to examine, interpret and understand the experience of the client of particular services and their relationship with the network of service providers (Hyden et al 2004).

While the governance scholarship has been influential in drawing our attention to the proliferation of multiple stakeholder arrangements it has not been without its critics (see for instance Mette Kjaer 2011; Bevir 2010). Some argue that Rhode's work fails to engage with tools from social and political economy and so neglects "important aspects of interests, power and conflict" with consequences for understanding the risks involved in the governance dynamic (Mette Kjaer 2011,101; Davies 2005). These critics call for greater engagement with the structural inequalities that predetermine and frame the emergent dynamics and subsequent outcomes of network 
governance structures in order to understand latent and direct conflict and power (Davies 2005; Fauser 2014).

Relatedly, the assumed processes of rulemaking have also been questioned. The implicit assumption within much of the governance scholarship is that there is consensus within networks regarding the approach to setting and adhering to rules. Bevir et al $(2003,5)$ note that: "Rules are always open to interpretation. It is not just a question of literal meaning but also a question of to whom the rule applies and of how to apply the rule in any given situation ...we must ask how beliefs, and so actions, are created, recreated and changed in ways that constantly reproduce and modify institutions." This point brings to bear a key weakness in the governance scholarship. Notably, agents with the greatest resources (financial, human and social capital for instance) are placed in a position of power, and able to determine the rules and, in doing so pursue and consolidate their own interests (see also Bevir 2010). Such a position then, challenges the notion of consensus and/or a level playing field within and between stakeholders and particularly between the agents and those drawing on their services where the latter group are also differentiated by access to resources (particularly financial). Importantly, consideration of the notion of accountability, appeals and sanctions in response to the exploitation or misappropriation of rules is also relevant here (Erkkila 2007).

There are various important implications of these weaknesses when related to the issue of migration and the complementary governance structures. For example de Haas (2010) is one of several migration scholars who implicitly captures the transition to network governance specifically within migration management and as such, draws attention to politico-economic and socio-structural factors. His research differentiates 
macro-level institutional arrangements, organisations located at the meso level, along with kinship and friendship ties, located at the micro level (see also Boyd 1989; Findlay and Li 1998; Gurak and Cases 1992; Martin 2006; Elrick and Lewandowska 2008; Massey et al 1998; Massey and Espinosa 1997; Salt and Stein 1997). This multi-scale analysis is important because the creation of new market actors at the global, national, regional, local and individual level not only affects migration trends but also influences power relationships within and between migrant groups and the agents with whom they undertake a transaction in the migration process.

Taken together, such insights allow us to re-interpret the boundaries of the migration governance structure while simultaneously incorporating institutional and structural arrangements (macro level considerations) with organisational and individual motivations/actions (meso and micro level considerations). As advocated by Findlay and $\mathrm{Li}(1998,701)$ we need to go beyond a single-level conceptualisation of migration management. By placing the meso-level of analysis (and the stakeholders located within it) at the centre of our investigation, this offers us a useful entry point as, "Such agencies link not only distant places around the globe, but also offer a middle ground linking individual human actions with the structuring influences of macro level sociopolitical and economic forces." These conceptual cues provide important tools for explaining and understanding the significant changes shaping migration processes for skilled migrants and the implications of these developments for the migrants involved.

\section{Scaling migration intermediaries and the role of meso-level commercial intermediaries}


A review of the main theories of migration illustrates the opportunities offered by migration theorists and the significant gaps in understanding migration intermediaries. A notable absence identified in the following overview is the meso-level of analysis and the stakeholders located in this sphere (Findlay and Li 1998; Elrick and Lewandowska 2008; Forde and Mackenzie 2011; Krissman 2005; Salt and Stein 1997).

In terms of macro-level research, the focus is largely on institutional arrangements, and includes investigations of relations between the sending and receiving countries, the rules that determine and facilitate this exchange and the way in which immigrant adjustment is satisfied (Lee 1966; Richmond and Zubrzycki 1984). While important in identifying the broad political and economic context of migration, the migrant's organisational and industrial and/or occupational identity has often remained invisible, as have the relations between them and the mediators of the migration and adjustment process.

At the other end of the spectrum, much of the micro-level analysis assumes that migrants transfer their individual human capital skills independently to host country labour markets in order to achieve higher financial returns than in the home country. Borjas (1991) notes that individuals rationally assess the relative costs and benefits of staying in their home country compared to gaining employment in a host country. Therefore, it is assumed that the migrant is driven by a utilitarian logic to labour mobility: moving unencumbered and unassisted from country to country. As McGovern (2007, 218) notes: "labour migrants are often described as the closest living embodiment of homo-economicus - that rational, self-seeking amoral agent." In this context, labour is considered another factor of production, drawn on when demanded and often freely mobile. 
Migrant behaviour and the activities of employers are thus reduced to a simple economic exchange, with little recognition of the 'intervening' support mechanisms shaping migration decisions and facilitating migration. That is, the power relationship between the agents of migration and the migrant is neglected. As a result the complex, human and dynamic elements of the migration and post-settlement adjustment phase are obscured. As noted, the rise of non-state actors in a market context has gone relatively unchecked and requires us to place the spotlight on these emergent players in the process of migration and labour market integration (Pijpers 2010)

The push-pull factor analysis offered by migration theorists (Portes and Borocz 1989), that compare labour migration to the flow of capital and trade neglect the role of critical agents who sit at the intersection of the push and pull dynamic, simultaneously influencing potential migrants to leave one country and move to another, or 'pulling' potential migrants at one point in time but 'pushing' them at another point in time. Such fundamental relational exchanges between the migrant and key intermediary stakeholders as enablers of the migration process requires more detailed analysis as they have significant flow-on effects for migration and integration outcomes (Forde and Mackenzie 2011; Salt and Stein 1997).

Migration network theorists go some way to identifying the processes within the structure of migration management. To this end, attention is turned to the significance of information exchanges and the institutional and social networks that shape migration processes (de Haas 2010; Elrick and Lewandowska 2008; Granovetter 
1973, 1985; Massey et al 1998). For instance, Bauer and Zimmerman $(1999,19)$ note that the process of information gathered through network ties is key to gaining access to the labour market, stating that such connections: “... lower the risks associated with migration to a foreign region, because individuals can expect help from previously migrated people to find a job in the destination country." This point captures the relational and dynamic nature of migrant decision-making. While useful, the network scholars largely neglect meso level stakeholders, instead privileging the macro or micro level arrangements (Krissman 2005; Kuptsch 2006; Mackenzie and Forde 2011; Sporton 2013). In spite of this, they draw our attention to the centrality of formal and informal information flows through network arrangements.

In this vein, the work of Goss and Lindquist $(1995,351)$ helpfully shows how network connections inform the process of migration and integration where these connections hold (variable) value for the migrant and the network with which they connect (see also Elrick and Lewandowska 2008, 722). Extending on this, de Haas (2010, 1589-1590) notes the distinction between the networks themselves and the resources that can be mobilised through such networks (see also Elrick and Lewandowska 2008, 722). This is important in the context of intermediaries because while in principle the services of agents are equally available to all migrants, the transactional, commercial and discretionary nature of these networks in the assistance offered around employment, legal and housing services for instance, means that in reality particular groups of migrants are channeled into different sectors of the labour market as a result of the variable quality and range of services provided. Driven by a business case approach to assistance in the process of migration and integration, migrants with fewer financial resources are disadvantaged by the transactional nature of the exchange between the migrant and the intermediary. This (unfairly) alters the 
power dynamic implicit in the exchange between the migrant worker and the host country labour market.

The nature of the (purchased) relationship and service between a migrant and an intermediary is a critical determinant of the success of the migration process and subsequent labour market integration. To illustrate, evidence drawn from OECD member states shows that skilled migrants who enter countries without 'substantial' information on the job entry or qualifications accreditation process experience greater difficulty entering the labour market in a position commensurate to their skills and qualifications. And because such information is often either not publically available, or migrants do not know how to gain access to it, the role of the intermediary is critical in facilitating this process. As a result, those who do not use intermediaries are potentially: "unutilised, that is, they are either unemployed or not in the labour force" (Chaloff and Lemaitre 2009,17; see also Cerna 2010) an outcome which reinforces pre-existing structural inequalities.

Research by Batalova et al $(2008,1)$ notes the human capital loss as a result of the downward mobility experienced by skilled migrants in the US where: "More than 1.3 million college-educated immigrants are unemployed or working in unskilled jobs such as dishwashers, security guards, and taxi drivers-representing one of every five highly skilled immigrants in the US labor force." In addition to the loss of skills due to brain waste, attrition rates of skilled migrants who struggle to adjust to the host country also raises concerns (Finch et al 2009; Oishi 2012; McKinsey Global Institute 2012; Wickramasekara 2003).

Increasingly, commercial interests and therefore a financial exchange between the 
migrant and origin and destination-country agents have come to play an important role in shaping the migration process as well as the pattern and implications of skilled migration more broadly (Coe et. al. 2010; Mahroum 2000). This conclusion reflects the view that "it is almost impossible to speak of migration management, or migration at all, without also speaking of the migration industry" (Gammeltoft-Hansen and Nyberg Sorensen 2006, 3; see also, Castles 2007; Elrick and Lewandowska 2008, 723 - 724). As such, an investigation examining the defining characteristics of this emergent industry and, particularly the mediators who facilitate the migration and post-settlement process, remains central to understanding the experience of skilled migrant workers today (van Hear et al 2012).

\section{The Three Phases of Relations between Migration Intermediaries and Skilled Migrants}

The marketisation of migration and the rise of the migration intermediary as a key player in this market-driven context, has both positive and negative implications, which are reflected in our examination of intermediary relations in the three phases of migration: with phase one incorporating mobilisation and attraction; phase two, allocation and labour market navigation/entry; and, phase three, allocation and integration (Iredale 2000; KPMG 2011; Wright 2012). While commercial interests have played a role in the management of migration throughout the Post World War II period, their proliferation and centrality in the mobilisation, allocation and integration of skilled migrants has been a more recent phenomenon.

Since the 1950s and up to and including the present, skilled migrants have relied on a variety of different agents to enable and facilitate the process of migration. In the immediate post-war period, agencies such as the Inter-governmental Committee for 
European Migration (ICEM, now known as the International Organisation for Migration $[\mathrm{IOM}])$ undertook most aspects of the migration facilitation process. Marks $(1957,487)$ captures the extensive roles and responsibilities of the ICEM:

\begin{abstract}
"A key factor in successful resettlement is the interchange of accurate information between the sending and receiving countries. ICEM has made interpretive films and film strips of Greece, Italy and the Netherlands, which are sent to the countries receiving migrants from those nations. Written materials describing the countries of emigration are also available. Conversely, prospective migrants require reliable background and facts so they have no illusions about the countries to which they are proceeding. Information on the people, labour conditions, social legislation, and the like, in the receiving countries, are available to emigrants in booklets in their native tongues. Supplementary film showings and lectures are frequently arranged. Further, language and orientation courses are offered to migrants before their embarkation, and are continued on board ICEM- chartered ships."
\end{abstract}

Intergovernmental organisations such as the ICEM demanded negligible costs and were relatively inclusive, focusing on the prospect of capacity building both for migrants and receiving countries. Such supranational agencies, many of which still operate today, have been guided by and are responsive to universally sanctioned rules and conventions, with structured, transparent, publically accountable, and institutionally framed migration management processes. These agencies have also been guided by and have gone on to inform the supply-driven approach to migration, which was largely the trend up until the late 1980 s when a market-driven approach to migration began to dominate (KPMG 2011; Wright 2012). The latter approach has spawned a greater emphasis on labour demand, particularly of skilled workers, as a key determinant of migration and thereby has consolidated the importance of multiple stakeholders in the attraction, allocation and integration of migrant labour.

Internationally, migration patterns have moved away from a focus on family reunion 
to a focus on skill and, an employer-driven approach to filling shortages with imported labour (OECD 2011; Papademitriou and Sumption 2011). For instance, Australia's skill visa stream now accounts for almost $70 \%$ of the total migrant intake (DIAC 2012a). The international preoccupation with skill demands is captured in a large-scale data survey conducted annually by ManpowerGroup, in which employers have emphasised their strong (and unmet) demand for skilled employees (ManpowerGroup, 2013). To service the growing demand for workers, (particularly skilled), migration pathways have become more flexible (Chaloff and Lemaitre 2009). For instance, in Australia there has been an increase in non-permanent and onshore migration; the introduction of State Specific and Regional Migration Schemes; Enterprise Migration Agreements, and; increased settlement outside main gateways. Currently $5 \%$ of Australia's total population are classified as temporary residents (Mares 2012). Similarly many states are introducing visas that target 'high rollers' or significant investors to attract foreign capital for business and infrastructure projects for instance (DIBP 2014).

The urgency to match migrant workers to jobs efficiently has generated a significant opportunity for migration intermediaries who have keenly capitalised on the market generated by such mobility. Certainly these commercially-driven agents are linked to and influenced by the actions and policies of macro-level institutions and may also be informed by the activities of migrant groups at the micro level. Notwithstanding the importance of these connections, the focus here is to provide an analysis of a small sample of important intermediaries who have emerged in the context of market liberalisation through identifying their intervention in three key phases. 
Located in both origin and destination countries, migration agents have become a critical source of information, connecting prospective migrants to jobs, accreditation authorities, educational institutions, housing and also assisting them with visa documents (Coe and Jordhus-Lier, 2010). While these agents may operate independently, there is an increasing presence of such service providers located within large multi-national professional service firms, such as Ernst and Young and Deloitte, explicitly linking the mobilisation and allocation process (phase one) to the allocation and labour market entry process (phase two). Services are used both in-house where there is a demand for managers or accountants with particular technical skills; or, the services of the migration agent are out-sourced to facilitate the attraction and deployment of skilled workers for clients.

In the UK there has been a five-fold increase in registered migration agencies in the decade from 2004-2014 (OISC 2014, 20). Similarly there has also been a steady growth in the number of migration agents in Australia (Australian Government 2014). In March 2014, there were approximately five thousand registered migration agents operating nationally; and this is complemented with a sizeable but unknown number of unregistered agents (Australian Government 2014, 4). Of those registered, 93\% indicated as operating for commercial ends (Department of Immigration and Citizenship 2012; Australian Government 2014), highlighting that the majority of these services requires a financial outlay from the migrant. Evidently, the costs and service quality are variable as notable by a search of 100 websites detailing such information (July - September, 2014, Australian Government Office of Migration Agents Registration Authority 2014; American Migration Agent Reviews 2014). It is 
safe to conclude then that the migrant's access to quality and efficient service is directly dependent on available financial resources. The use of services offered by migration agents is captured in studies by Hardill and MacDonald (2000) and Buchan et. al. (2005) who examine the relationship between migration agents and nurses in the process of migration. Both studies reveal the financial outlay made by the nurse for information on the qualifications accreditation process, employment information, visa assistance, transport and post-settlement accommodation. In short, the evidence they present builds a compelling case indicating that those with ready and available financial capital gain access to information while those with fewer resources are left vulnerable in a foreign system which is serviced by largely unmonitored agencies and a lack of enforced base levels of training for the service providers (Hakak and $\mathrm{Al}$ Ariss 2013).

\section{Phase 2: Allocation and Labour Market Entry/Navigation}

Recruitment agents have played a significant role in linking migrants to employment throughout the history of migration (Elrick and Lewandowska 2008). Over the course of the last three decades this industry has expanded significantly and has come to play an important role in the facilitation of sourcing skilled workers (nationally and internationally) to satisfy the demands of the host country labour market (Coe. et. al. 2010; Forde, 2008; Forde and Mackenzie 2011; Gonos, 1997; Hoque et. al. 2011; McDowell et. al. 2007). While variable codes of conduct regulate both recruitment and migration agents, monitoring is ad hoc (Forde, 2008; Forde and Mackenzie, 2011; Castles and Miller, 2009). The following examines the implications of this growing migration intermediary for migrant workers.

In 1997 the ILO estimated that approximately 80 percent of the temporary movement 
of migrants from Asia to the Arab states was mediated by private recruitment agencies (Demaret ILO 2006 in Agunias 2012, 2; see also Newland 2013, 8). Agunias notes that in spite of the lack of up-to-date and comparable estimates, it is safe to assume that, "private agencies continue to account for the vast majority of contract labour migration flows to the region" (Agunias 2012, 2; see also Rahman 2011; van Hear et al 2012; Ward et al 2001). As brokers between the migrant and the destination labour market, evidence shows they have both positive and negative implications for the migrant drawing on their services which largely revolve around financial and nonfinancial costs founded on what is described as a minimal compliance/business case model of service delivery (Agunias 2012, 9; Forde and Mackenzie 2011).

For instance, Agunias (2013) notes that in areas of high demand the cost of using an employment agency is devolved to the employer. To illustrate, the health sector provides a useful case in point, where "a survey of nurse recruiters in the United States found that a substantial majority ( 82 percent) do not charge migrant nurses an up-front fee" $(2013,6)$. However, concerns are brought to light in our examination of particular groups of migrant nurses where, an ethnic penalty is imposed by the recruitment agent. Forde and Mackenzie $(2011,33)$ note that a business case logic to employment agency operations has served to consolidate race, gender and class divisions and therefore labour market segmentation along these lines, a point which is illustrated in the following example drawing on migrant nurses.

Newland $(2013,9)$ argues that in spite of the implementation of agreements established to monitor employment agents, “... the bilateral agreement between the government of the United Kingdom and the Philippines resulted in only 200 nurses recruited into the UK National Health Service; while private medical facilities, which 
were not covered by the agreement, recruited 2,000 Filipino nurses in the same period" (see also Buchan 2001; Buchan et al 2005). While the market mechanism can act in the interests of many skilled migrants, particularly in areas of high demand, it can also result in a pecking order of attraction and therefore segmentation based on ethnicity for instance, emphasising that dependence on commercially-driven intermediaries may result in a reinforcement and reproduction of structural inequalities.

For skilled migrants who seek access to the destination labour market but do not hold the relevant (commensurate) credentials, educational institutions have also become important agents in facilitating labour market entry through the provision of for instance: language classes, bridging courses for accreditation purposes and degree and diploma courses (Hawthorne, 2008). While educational institutions offer opportunities for re-accreditation and therefore access to the destination labour market in a position that reflects skills and qualifications, access often comes at substantial cost, both in terms of the educational product purchased and in terms of time out from active labour force participation. This places the burden of risk of migrating; and, gaining access to and integrating into the destination labour market in the hands of the migrant while also creating inequitable access given the importance placed on financial capital.

\section{Phase 3: Allocation and Integration}

As an important non-state agent, the transforming migration context has placed employers in a significant position, in the attraction, allocation and integration of skilled migrants globally (The Independent, 2013; Mares 2012; OECD 2012). Unlike supply-driven migration based on the points system, where the state determines 
criteria against which skilled migrants can apply to enter a country, the demanddriven (and often relatedly, temporary) migration process relies explicitly on market indicators to determine to whom and how labour market access is granted. Noting the shift away from supply-driven to employer-driven migration in the United States, Papademetriou and Sumption $(2011,1)$ argue that this approach goes some way to respond to the underutilisation of skills as a result of difficulties in qualifications accreditation and/or integrating into the host country labour market. The organisational context has therefore become central to the integration of skilled migrants.

Alternatively, the migrant's dependence on the employer for their continued legal and legitimate employment status raises concerns, founded on the unequal power dynamic between the sponsor (employer) and migrant (Elrick and Lewandowska 2008; Wright 2012). Furthermore, over time a bloated imported labour reserve may in fact place downward pressure on local wages increasing tensions between local and imported labour while also creating artificial segments in the labour market with migrants channeled into less desirable and less financially rewarding areas (Batalova et. al. 2008; Reitz 2005).

The three phases presented and the illustrative examples for each phase highlight a significant degree of overlap between these categories. What is clear is that the intermediaries shape and impact on the migration and labour market integration process in various (and intersecting) ways. Over the last two to three decades migration management has moved to a largely fee-driven exchange between migrant and intermediary, granting the intermediary discretionary powers in what is a largely market-driven and often weakly regulated migration process. Given that migration 
intermediaries charge a range of fees for their services, access to and the quality of intermediary networks, is increasingly determined by the financial capital resources of skilled migrants (van Hear 2004). As a corollary, the greater the breadth and depth of the relationship forged and the resources used in this process by the migrant, the weaker the financial and non-financial risks in the migration process, which can include: loan repayments to the intermediary, downward mobility, an inability to gain skills and qualifications accreditation, and an inability to integrate in the host country labour market (Jayati 2009; OECD 2012).

\section{Conclusion}

As in many other areas of the economy, market liberalisation and a disarticulation of state interventions (Favell and Hanson 2002; Fauser 2014) have created market opportunities for new actors in the process of global mobility. Drawing on the shift from government to network governance, the paper demonstrates that while skilled migrants still rely on friendship/kinship ties (micro level arrangements) or institutional directions (macro level arrangements) to facilitate migration, there has been an increasing reliance on a fast developing migration industry (Castles 2007; Elrick and Lewandowska 2008). This means that reliable intermediary services may often be restricted to migrants who have considerable financial resources, while those with more limited resources take what they can get (Elrick and Lewandowska 2008; Pijpers 2010).

This increasingly transactional exchange between the migrant and intermediary recasts, greater responsibility (and arguably power and control) in the hands of variably regulated intermediary actors who offer variable services in terms of quality. 
Second, while migrant choice and motivation based on career advancement or citizenship, play an important role in intermediary engagement (Findlay and Li, 1998), greater focus on the potential purchasing capacity and migrant access to quality information is also important (van Hear 2004). In short, labour market and settlement outcomes are increasingly influenced by the relationship 'purchased' with agents, placing the risk of migration firmly in the hands of the migrant. Third, access and equity issues mean that some groups of migrants are excluded from access to information and as such experience downward mobility, which reinforces structural inequities. Future research could further investigate the changing transactional exchanges between the migrant and the intermediary by examining each of the intermediaries and their relationship with particular groups of migrants in different geographic and sectoral contexts.

As discussed above, the three phases of intermediary intervention are not mutually exclusive and intermediaries may well be located within more than one phase of the migration/labour market allocation and integration categories presented, particularly as some intermediaries become a 'one-stop' shop style provider of migration services (Forde 2008). While so, relations and interaction between these agents within the various phases occurs on an ad-hoc basis making the process of gaining information from a suite of agents more difficult to achieve for migrants. Future research could also examine exactly how these agents operate and the implications of a disjointed collaboration between the various intermediaries for the migrants seeking an efficient transition into the destination country. 
Notably, the relationship struck between the migrant and the intermediary is not only held together by the potential of a financial gain for the information and assistance offered but also by different conventions (formal: legal and policy; and informal: cultural context and customs), which remain a largely unexplored facet of the migration exchange process (Elrick and Lewandowska 2008). These conventions provide legitimacy to the information offered; set the expectations between the various stakeholders involved in the exchange; and depending on the foundations of exchange as driven by the convention, may go on to perpetuate the process of exchange over time. Such conventions also inform the process of decision-making (which determines the accepted exchange relations between migrant and intermediary) and consolidate the power dynamics between the migrant and the intermediary. Importantly, such conventions are loosely based on policy direction from the state but are not governed by legally enforced restrictions and (potential) sanctions (Harvey and Groutsis 2012; Forde and Mackenzie 2011). Therefore, an understanding of conventions forged in the market domain is of paramount importance. Presently, one could question how these new agents could be more closely monitored, and regulated. Future research would need to examine the monitoring process and the effect of the power dynamics between intermediaries and different groups of skilled migrants, to make more transparent what is often a very opaque and poorly analysed aspect of the migration process.

\section{References:}

Agunias, D. R. 2012. "Regulating Private Recruitment in the Asia-Middle East Labour Migration Corridor" Issue In Brief, Migration Policy Institute Issue No. 4 (August): $1-12$.

Agunias, D. R. 2013. "What we know about regulating the recruitment of migrant workers” MPI Policy Brief, Washington DC: Migration Policy Institute. 
American Migration Agent Reviews. 2014. Retrieved July-September 2014 http://migrationagentreviews.com/america-reviews.html

Australian Government. 2014. Office of Migration Agents Registration Authority (MARA). Migration Agent Activity Report Url: https://www.mara.gov.au/media/282227/MAAR_Jan_Mar_2014_Web.pdf

Australian Government. 2014. Office of Migration Agents Registration Authority (MARA). Listed Migration Agents, Retrieved July-September 2014, https://www.mara.gov.au/search-the-register-of-migration-agents/

Batalova, J. A., M. Fix. with P. A. Creticos. 2008. Uneven Progress the Employment Pathways of Skilled Immigrants in the United States, Migration Policy Institute, Washington DC: National Center on Immigrant Integration Policy.

Bauer, T. K., and K. F. Zimmermann. 1999. Assessment of possible migration pressure and its labour market impact following EU enlargement to central and Eastern Europe (IZA Research Report No. 3) Bonn, Germany: Institute for the Study of Labor.

Becker, R., and R. Kolster. 2012. International student recruitment: policies and developments in selected countries Netherlands Organisation for International Cooperation in Higher Education (January) 2012.

Bevir, M., R.A.W. Rhodes and P. Weller. 2003. "Traditions of Governance: Interpreting the Changing Role of the Public Sector." Public Administration, Special Issue 81(1):1-17.

Bevir, M. 2010. Democratic Governance, Princeton New Jersey: Princeton University Press.

Borjas, G. J. 1991. "Immigration and self-selection" 29-76, in John Maron Abowd, and Richard B Freeman, eds, Immigration, Trade, and the Labor Market. Chicago: University of Chicago Press.

Boyd, M. 1989. "Family and Personal Networks in International Migration: Recent Developments and New Agendas." International Migration Review 23(3) 638-70.

Buchan, J. 2001. "Nurse Migration and International Recruitment." Nursing Inquiry 8(4) 203 - 204 (December) 2001

Buchan, J., R. Jobanputra, and P. Gough. 2005. "Should I stay or should I go?", Nursing Standard, 19, 36, 14-16.

Castles, S. 2007. "Twenty-first century migration as a challenge to sociology" Journal of Ethnic and Migration Studies, 33(3): 351-71.

Castles, S., and M. J. Miller. 2009. The Age of Migration, International Population Movements in the Modern World (Fourth Edition). U.S. Palgrave Macmillan. 
Cerna, L. 2010. "Policies and practices of highly skilled migration in times of the economic crisis", International Migration Programme, International Migration Papers No. 99. Geneva: International Labour Organisation.

Chaloff, J., and G, Lemaitre. 2009. Managing Highly-Skilled Labour Migration: A Comparative Analysis of Migration Policies and Challenges in OECD Countries, OECD Social, Employment and Migration Working Papers, No 79, 18 March 2009. Paris: OECD.

Ciupijus, Z. 2011. "Mobile central eastern Europeans in Britain: successful European Union citizens and disadvantaged labour migrants?" Work Employment and Society 25(3): 540-550.

Coe. N. M., K. J. Jones, K. Ward. 2010. "The Business of Temporary Staffing: A Developing Research Agenda", Geography Compass 4/8 (2010): 1055-1068.

Coe. N.M., and D. C. Jordus-Lier. 2010. "Constrained agency? Re-evaluating the geographies of labour", Progress in Human Geography, 35, 2, 211-233.

Davies, J. 2005. "Local Governance and the Dialectics of Hierarchy, Market and Network." Policy Studies, 26 (3-4): 311-35.

de Haas, H. 2010. "The Internal Dynamics of Migration Processes: A Theoretical Inquiry." Journal of Ethnic and Migration Studies 36(10): 1587-1617.

Demaret, L. 2006. "Private Employment Agencies: The Challenges Ahead from the Workers' Perspective" in Christiane, Kuptsch (ed) Merchants of Labor. Geneva: International Labour Organization.

Department of Immigration and Border Protection. 2014. What is the Significant Investor Visa? Retrieved 15 October 2014, from http://www.immi.gov.au/faqs/Pages/What-is-the-significant-investor-visa.aspx

Department of Immigration and Citizenship. 2008-2009. Immigration Update. Retrieved $29 \quad$ January $2010, \quad$ from http://www.immi.gov.au/media/publications/statistics/immigration-update/updatejun09.pdf

Department of Immigration and Citizenship. 2012. Migration Agent Activity Report: Quarterly report on the provision of immigration assistance in Australia (January - March 2012), Department of Immigration and Citizenship, Australian Government, Canberra.

Department of Immigration and Citizenship. 2012a. Fact Sheet, Retrieved 20 November 2012 http://www.immi.gov.au/media/fact-sheets/24overview_skilled.htm

Elrick. T., and E. Lewandowska. 2008. "Matching and Making Labour Demand and Supply: Agents in Polish Migrant Networks of Domestic Elderly Care in Germany and Italy" Journal of Ethnic and Migration Studies, 34(5): 717-734. 
Erkkila, T. 2007. "Governance and Accountability - A Shift in Conceptualisation". $P A Q$ (Spring) 2007: 1 - 38 .

Fauser, M. 2014. "Co-development as Transnational Governance: An Analysis of the Engagement of Local Authorities and Migrant Organisations in Madrid" Journal of Ethnic and Migration Studies 40(7): 1060-1078.

Favell, A., and R. Hansen. 2002. "Markets against politics: migration, EU enlargement and the idea of Europe" Journal of Ethnic and Migration Studies, 28(4): 581-601.

Fernandez, B. 2013. "Traffickers, Brokers, Employment Agents, and Social Networks: The Regulation of Intermediaries in the Migration of Ethiopian Domestic Workers to the Middle East" International Migration Review 47(4): 814-843.

Finch, T., M. Latorre, N. Pollard, and J. Rutter. 2009. Shall We Stay Or Shall We Go? Re-migration trends among Britain's immigrants, Great Britain: Institute for Public Policy Research.

Findlay, A. M., and F. L. N. Li. 1998. "A Migration Channels Approach to the Study of Professionals Moving to and from Hong Kong" International Migration Review, 32(3) (Autumn, 1998): 682-703.

Forde, C. 2008. "You know we are not an Employment Agency": Manpower, Government, and the Development of the Temporary Help Industry in Britain, Business History Conference, 337-365, Oxford: Oxford University Press.

Forde, C., and R. MacKenzie. 2011. "The Ethical Agendas of Employment Agencies Towards Migrant Workers in the UK: Deciphering the Codes." Journal of Business Ethics 97.1: 31-41.

Gammeltoft-Hansen, T., and N. Nyberg Sorensen. 2013. The Migration Industry and the Commercialization of International Migration. London, New York: Routledge.

Geddes, A., W. N. Adger, N. W. Arnell, R. Black, D. S. G. Thomas. 2012a "The implications for governance of migration linked to environmental change: key findings and new research directions." Environment and Planning C: Government and Policy 30(6): 1078 - 1082.

Geddes, A., W. N. Adger, N. W. Arnell, R. Black, D. S. G. Thomas. 2012b. "Migration, environmental change, and the "challenges of governance." Environment and Planning C: Government and Policy 30(6): 951 - 967.

Gonos, G. 1997. "The Contest over 'Employer Status' in the Post-War United States: The Case of Temporary Help Firms," Law and Society Review 31, no. 1 (1997): 81110.

Goss, J., and B. Lindquist. 1995. "Conceptualizing international labor migration: A structuration perspective." The International Migration Review 29(2): 317-351. 
Granovetter, M. S. 1973. "The Strength of Weak Ties." American Journal of Sociology 78(6):1360-80.

Granovetter, M. S.1985. "Economic Action and Social Structure: The Problem of Embeddedness." American Journal of Sociology 91(3): 481-510.

Gurak, D., T, and F. Caces. 1992. "Migration Networks and the Shaping of Migration Systems." in Mary M. Kritz, Lin Lean Lim, and Hania Zlotnik (eds), International Migration Systems: a Global Approach (Clarendon Press, Oxford).

Hakak, L. T., and A. Al Ariss. 2013. "Vulnerable Work and International Migrants: a relational human resource management perspective" International Human Resource Management, 24 (22): 4116-4131.

Hardill, I. and S. MacDonald. 2000. "Skilled International Migration: The Experience of Nurses in the UK", Regional Studies, 34, 7, 681-692.

Harvey, W. S., and D. Groutsis. 2012. "Skilled migrants in the Middle East: definitions, mobility and integration" International Journal of Business and Globalisation, 8(4): 438-53

Hawthorne, L. 2008. The Growing Global Demand for Students as Skilled Migrants, Migration Policy Institute, Washington DC.

Hoque, K., I. Kirkpatrick, C. Lonsdale, A. De Ruyter. 2011. "Outsourcing the procurement of agency workers: the impact of vendor managed services in English social care", Work Employment and Society 25(3): 522-539.

Hyden, G., J. Court and K. Mease. 2004. Making Sense of Governance. Empirical Evidence from 16 Developing Countries. Boulder,CO: Lynne Rienner.

Hysing, E. 2009. "From Government to Governance? A Comparison of Environmental Governing in Swedish Forestry and Transport." Governance an International Journal of Policy, Administration, and Institutions. 22(4):647-672.

Iredale, R. R. 2000. "Migration policies for the highly skilled in the Asia-Pacific region” The International Migration Review. 34(3): 882- 906.

Jayati, G. 2009. Migration and Gender Empowerment: Recent Trends and emerging issues. Available at: http//mpra.ub.uni-muenchen.de/19181/MPRA Paper No 19181, posted 11 December 2011.

Kontos, M. 2011. "Between Integration and Exclusion: Migrant Women in European Labor Markets" Migration Policy Institute Available: http://www.migrationpolicy.org/ Retrieved 10 August 2012.

KPMG. 2011. Plugging those vital skill gaps, Skilled Migration Survey 2011 Australia: KPMG. 
Krissman, F. 2005. "Sin coyote ni patrón: Why the 'migrant network' fails to explain international migration”. International Migration Review. 39(1): 4-44.

Kuptsch, C. (ed). 2006. Merchants of Labour US: International Institute of Labour Studies.

Lee, E. S. 1966. “A Theory of Migration.” Demography 3(1): 47-57.

Leman, J., and S. Janssens. 2007. "The Various 'Safe'-House Profiles in EastEuropean Human Smuggling and Trafficking" Journal of Ethnic and Migration Studies 33 (8): 1377-1388.

McDowell, L., A. Batnitzky, and S. Dyer. 2007. "Division, Segmentation, and Interpellation: The Embodied Labors of Migrant Workers in a Greater London Hotel", Economic Geography 83(1): 1-25.

McGovern, P. 2007. "Immigration, Labour Markets and Employment Relations: Problems and Prospects." British Journal of Industrial Relations, Special Issue: Political Economy of Migration 45 (2): 217-235.

McKinsey Global Institute Prepared by Dobbs, R. Madgavkar, A. Barton, D. Labaye, E. Manyika, J. Roxburgh, C. Lund, S. Madhav, S. 2012. The world at work: Jobs, pay, and skills for 3.5 billion people US: McKinsey and Company.

Malmstron, C. 2012. Employment: Commissioners Malmström and Andor welcome the new OECD report on international migration trends, Reference: MEMO/12/495 Event Date: 27/06/2012.

Marks, E. 1957. "Internationally Assisted Migration: ICEM Rounds out five years of Resettlement” International Organisation 11(3): 481 - 494.

Mahroum, S. 2000. "Highly skilled globetrotters: mapping the international migration of human capital." $R \& D$ Management 30(1): 23-32.

ManpowerGroup. 2013. 2013 Talent Shortage Survey Research Report, ManpowerGroup.

Mares, P. 2012. "Temporary Migration and its Implications for Australia." Papers on Parliament No. 57, (February) 2012.

Marinetto, M. 2003. "Governing Beyond the Centre: A Critique of the Anglogovernance School.” Political Studies, 51(3): 592-608.

Martin, P. 2003. Highly Skilled Labor Migration: Sharing the Benefits, International Institute for Labour Studies (May) Geneva: International Labour Organisation.

Martin, P. 2006. Managing Labor Migration: Temporary Worker Programmes for the $21^{\text {st }}$ Century, International Symposium on International Migration and Development, 
Population Division, Department of Economic and Social Affairs United Nations Secretariat Turin, Italy, 28-30 June 2006.

Massey, D. S., and K. E. Espinosa. 1997. "What's Driving Mexico-US Migration? A Theoretical, Empirical, and Policy Analysis." American Journal of Sociology 102(4): 939-999.

Massey, D. S., J. Arango, G. Hugo, A. Kouaouci, A. Pellegrino and J. Edward Taylor 1998 Worlds in Motion: Understanding International Migration at the End of the Millennium Oxford:Clarendon Press.

Mette Kjaer, A. 2011. 'Rhodes' contribution to governance theory: praise, criticism and the future governance debate'. Public Administration, 89(1): 101-113.

Morawska, E. 1990. "The Sociology and Historiography of Immigration” in Virginia Yans-McLaughlin (ed) Immigration Reconsidered New York: Oxford University Press.

Newland, K. 2013. 'What we know about migration and development'. MPI Policy Brief, Washington DC: Migration Policy Institute.

Office of the Immigration Services Commissioner (OISC). 2014. Annual Report and Accounts 2013/14. http://oisc.homeoffice.gov.uk/servefile.aspx?docid=399

Oishi, N. 2012. "The limits of immigration policies: The challenges of highly skilled migration in Japan." American Behavioral Scientist 56(8):1080-1100.

OECD. 2001 compiled by Clarke R, Durand M, \& Pilat D T R, The New Economy: Beyond the Hype. The OECD Growth Project Washington: OECD Publishing.

OECD. 2011. International Migration Outlook: SOPEMI 2011. Paris: Organisation for Economic Cooperation and Development.

OECD. 2011. Towards an OECD Skills Strategy, Meeting of the OECD Council at Ministerial Level, Paris, 25-26 May 2011.

OECD. 2012. Harnessing the skills of migrants and diasporas to foster development: policy options, Directorate General of Global Affairs Development and Partnerships (September) Paris: OECD.

Papademetriou, D. G. 2003. "Policy Considerations for Immigrant Integration." Migration Policy Institute (October) 2003,Available: http://www.migrationpolicy.org/ Retrieved 10 August 2012

Papademetriou, D. G., and M. Sumption. 2011. Rethinking Points Systems and Employer-Selected Immigration. Washington, DC: Migration Policy Institute.

Pijpers, R. 2010. "International Employment Agencies and Migrant Flexiwork in an Enlarged European Union" Journal of Ethnic and Migration Studies 36(7): 10791097. 
Portes, A., and J. Borocz. 1989. "Contemporary Immigration: Theoretical Perspectives on Its Determinants and Modes of Incorporation" International Migration Review Special Silver Anniversary Issue: International Migration an Assessment for the 90's 23(3): 606-630.

Productivity Commission Research Report. 2006 Economic Impacts of Migration and Population Growth Canberra: Productivity Commission, Australian Government.

Rahman M. 2011. "Recruitment of Labour Migrants for the Gulf States: The Bangladeshi Case" Institute of South Asian Studies (ISAS) Working Paper No. 132 - 6 (September) $1-24$.

Ray, B. K. 2002. "Immigrant Integration: Building to Opportunity" Migration Policy Institute. Available: http://www.migrationpolicy.org/ Retrieved 10 August 2012.

Reitz, J. G. 2005. "Tapping Immigrants' Skills: New Directions for Canadian Immigration Policy." Law and Business Review of the Americas. (Summer 2005) 11(3/4): 409-432.

Rhodes, R. A. W. 1997. Understanding Governance Buckingham Place Philadelphia: Open University Press.

Rhodes, R. A. W. 1998. "Different roads to unfamiliar places: UK experience in comparative perspective." Australian Journal of Public Administration. 57(4):19-31.

Rhodes, R. A. W. 2003. "Putting the people back into networks." Australian Journal of Political Science. 37(3): 399-415.

Rhodes, R. A. W. 2007. "Understanding Governance: Ten Years On." Organization Studies 28(8):1243-1264.

Richmond, A. H., and J. Zubrzycki. 1984. Immigrants in Canada and Australia Vol. 2 Toronto: York University, Institute for Behavioural Studies.

Salt, J., and J. Stein. 1997. "Migration as a Business: The Case of Trafficking"International Migration 35(4): 467-494.

Spener, D. no date. Some Critical Reflections on the Migration Industry Concept Department of Sociology and Anthropology, Trinity University San Antonio, Texas U.S.A. Available at: http://www.trinity.edu/dspener/clandestinecrossings/related\%20articles/migration $\% 20$ industry.pdf

Sporton, D. 2013. “'They Control My Life': the Role of Local Recruitment Agencies in East European Migration to the UK, Population." Population, Space and Place, 19(5):443-458.

Straubhaar,T. 2000. International Mobility of the Highly Skilled: Brain Gain, Brain Drain or Brain Exchange Hamburg Institute of International Economics, HWWA Discussion Paper 88.

Tanner, A. 2011. "Finland's Balancing Act: The Labor Market, Humanitarian Relief, and Immigrant Integration" Migration Policy Institute Available: http://www.migrationpolicy.org/ Retrieved 17 August 2012. 
The Independent. 2013. "UK relies on migration to fill one in five skilled jobs as experts warn of major 'skills shortage'." The Independent, Monday 4 November 2013.

Triandafyllidou, A., and T Maroukis. 2012. Migrant Smuggling. Irregular Migration from Asia and Africa to Europe, London: Palgrave Macmillan.

van Hear, N., O. Bakewell, and K. Long. 2012. "Drivers of Migration, Migrating out of Poverty." Research Programme Consortium Working Paper 1 March 20121 - 43.

van Hear, N. 2004. 'I went as far as my money would take me': conflict, forced migration and class, Centre on Migration, Policy and Society Working Paper No. 6 University of Oxford, WP-04-06. Available at: http://www.compas.ox.ac.uk/fileadmin/files/Publications/working_papers/WP_2004/ WP0406.pdf

Ward, K., D. Grimshaw, J. Rubery, and H. Beynon. 2001. "Dilemmas in the management of temporary work agency staff." Human Resource Management Journal 11(4): 3-21.

Wickramasekara, P. 2003. Policy responses to skilled migration: Retention, return and circulation, Perspectives on Labour Migration 5E, Social Protection Sector, International Migration Programme (International Labour Organisation, Geneva).

Wright, C. F. 2012. "Immigration policy and market institutions in liberal market economies.” Industrial Relations Journal 43(2): 110-136. 